\title{
Population and its Impact on Level of Unemployment in Least Developed Countries: An Appraisal of the Nigerian Economy
}

Imoisi Anthony llegbinosa ${ }^{1^{*}}$, Olatunji Lekan Moses ${ }^{2}$ and Ubi-Abai Itoro Praise ${ }^{3}$

${ }^{1}$ College of Social \& Management Sciences, McPherson University, Ogun State, Nigeria

${ }^{2}$ School of Graduate Studies, Faculty of Social Sciences, Department of Economics, University of Port Harcourt, Rivers State, Nigeria

${ }^{3}$ School of Graduate Studies, Faculty of Social Sciences, Department of Economics, University of Uyo, Akwa-Ibom State, Nigeria

*Corresponding author: Dr. Imoisi, Anthony llegbinosa, College of Social \& Management Sciences, McPherson University, Seriki Sotayo, Km 96, Lagos-lbadan Expressway, P.M.B. 2094, Abeokuta, Ogun State, Nigeria, Tel: +80-34-525-743; E-mail: mcanthonyby@yahoo.co.uk

Received date: September 30, 2013, Accepted date: September 27, 2014, Published date: October 07, 2014

Copyright: (C) 2014 llegbinosa IA, et al. This is an open-access article distributed under the terms of the Creative Commons Attribution License, which permits unrestricted use, distribution, and reproduction in any medium, provided the original author and source are credited.

\begin{abstract}
This paper deals with the population and the problem of unemployment in LDCs. The economies of the LDCs are characterized by high population growth. They are facing great challenge in generating adequate job opportunities for their teeming population. Many facts and data from notable authors, agencies, websites and organizations were analyzed and discussed in this paper regarding this problem. Nigeria is not left out as their population ever increases with limited number of job opportunities. The factors responsible for the increase in the level of unemployment in Nigeria includes: rural urban migration, wrong government policies, urban bias, lack of population control, lack of mental skill and practicability, corruption and Inspirited Entrepreneur drive. Reviewing the socioeconomic organization, monitoring rural-urban migration, promoting agriculture and entrepreneurship programmes, Investment in human capital, and encouraging Public Private Partnership etc. were some of the recommendations made to avoid a "worst-case scenario" of the above problem and to realize the nation's vision as being one of the leading economies by the year 2020 .
\end{abstract}

Keywords: Population growth; Unemployment; Public private partnership; Rural-urban migration; Corruption; Entrepreneur drive; Least developed countries

\section{Introduction}

The economies of the Least Developed Countries (LDCs) are typified by high level of population growth. Population is a very helpful feature as soon as it approaches demographic dividendengaging the crowded youths of the populace in productivity. In 2011, the population of the world arrived at 7 billion and by 2050 it would increase in excess of 9 billion. At the moment, approximately 855 million people are residing in the LDCs. The total population of the 48 least developed countries is rising today almost twice as rapid as that of the developing world: at $2 \%$ per annum and $1.2 \%$ annually. Over the subsequent forty years the LDCs populace will rise by approximately $100 \%[1]$.

The LDCs populace has significant tests if the characters intrinsic in it are under-utilized to optimum capacity. Maybe, they are about to confront the greatest test in times gone by, creating adequate amount of jobs at reasonable salaries to take in their fast growing populations into industrious employment.

Nigeria has been experiencing population explosion for the past $50 y e a r s$ due to high fertility rates, quadrupling its population overtime. On the day the Nigeria Population Commission (NPC) announced that our population was now a staggering 167, 912, 561 and is projected to hit 221, 392, 163 by July 1,2020, hardly anyone paid attention. As described by the Regional Head of Research, Africa Global Research, Standard Chartered Bank, Razia Khan, "Nigeria's big concern of course is whether sufficient employment opportunity can be generated to absorb the country's growing pool of labour, and whether this can take place rapidly enough" (See www.NigeriaHealthwatch.com). Employment crisis, manifested in various forms of underemployment rather than open employment, have been the core problem plaguing the LDCs. This is partly due to high population growth rocking the LDCs. This is of serious concern to the citizens, economists, government and other analysts in the economy. This paper is guided by the following objectives: to examine population and employment trends in LDCs; to examine the population profile of Nigeria and to identify the factors responsible for the increased employment problems in Nigeria.

\section{Review of Related Literature}

More than two centuries ago reverend Thomas Malthus, in his "Essay on the principles of population" postulated the threshold population level at which population increase was bound to stop because life-sustaining resources, which increase at an arithmetic rate, would be insufficient to support human population, which increases at a geometric rate. Consequently, there is the tendency for population to outrun the means of subsistence, if nothing is being done to check the growth of population. It would be important to note that some LDCs' problems are not due to lack of resources but mismanagement and corruption.

The employment problem, which includes open unemployment, underemployment, low wage employment, social exclusion, idleness etc., is noticeable in almost every market economy today. They are, however, more serious in the LDCs than in the Developed Countries. Commenting on the issue of unemployment in Cameroun and Ethiopia, Richard Curtain, a Professional Associate of the National Institute for Governance, Australia [2] opined that "Unemployment is 
still high among young people, moreover, and is exacerbated by the mismatch between vocational training and the employment needs of the economy. Unemployment manifests itself mainly in the form of underemployment. Open unemployment is concentrated in the urban areas. Youth unemployment is a major social problem." This indicates the extent to which the problem of employment has really eaten into the economy of LDCs like a cankerworm.

According to the International Labour Organization (ILO) (See www.ilo.org), "unemployment is the share of labour force without work but available for and seeking employment". Truly, those who are capable and enthusiastic to work nevertheless cannot find jobs at the current wage rate constitute a large share in the LDCs. According to Godday Odidi (Quoted from his article "Tackling youth unemployment: The way forward (www. the nigeriavoice.com), "Unemployment is defined as a state of people living in absolute joblessness which range fall between the ages of 20-40 while underemployment is a situation where people who are gainfully employed but not financially rewarding to authenticate their qualifications".

\section{Population and Unemployment Trends in the Least Developed Countries (LDCs)}

As described by the United Nations Conference on Trade and Development, the LDCs represent the poorest and weakest segment of the international community. Extreme poverty, the structural weaknesses of their economies and the lack of capacities related to growth, often compounded by structural handicaps, hamper efforts of these countries to improve the quality of life of their people [1].

Since 1950, the populations of LDCs have increased tremendously, most of which are considered to have at least quadrupled. According to the no-change scenario of the United Nations, these populations are expected to increase multiple times by 2100 due to the high levels of fertility. With constant levels of fertility and mortality, Niger's population would increase 57 times, Uganda's population 4 times, and the population of Timor-Leste by almost 1 time. Only Afghanistan, Guinea, Guinea - Bissau and Timor-Leste has seen a mere tripling of their populations [3]. Such predictions would be a source of worry if the least LDCs, whose population growth rate triples that of the developing countries, are unable to meet the vast needs of growing numbers of people. Apart from the fast rate of population growth; the LDCs suffer from high dependency ratio - the proportion of the nonworking population of a country to the total population. Because of the high dependency ratio, there is a lot of pressure on the resources.

Table 1 illustrates the annual growth rate of working-age and nonworking-age (dependent) population. The dependent population of Nigeria was the same as that of Sub-Saharan Africa (2.6\%). Pakistan $2.5 \%$, followed by Indonesia $0.9 \%$ and East Asia $0.5 \%$. They are projected to reduce if proper structures and frameworks are designed appropriately.

The problem of unemployment appears to be more serious in LDCs' cities than in the rural areas. This is due mainly to the fast growth of cities in this countries and the inability of these cities to provide jobs for their growing population. The fast growing cities in the LDCs is illustrated by the following Table 2 .

Here, all cities' populations are projected to increase. Population of some of these fast-growing cites have surpassed such projections. According to Egon Cossou (See article online - www.bbc.co.uk "Lagos aims to be Africa's model mega city"), "the population of Lagos hit 18 million......" This increase, juxtaposed with the problem of unemployment, would be as a result of non-absorptive employment opportunities for the large number of youths occasioned by increased Rural - urban migration.

\begin{tabular}{|l|l|l|l|l|l|}
\hline \multirow{2}{*}{ S/N } & \multirow{2}{*}{ Country } & \multicolumn{2}{|l|}{$\mathbf{1 9 7 0 - 2 0 1 0}$} & \multicolumn{2}{l|}{$\mathbf{2 0 1 0 - 2 0 5 0}$} \\
\cline { 3 - 6 } & & $\begin{array}{l}\text { Dependent } \\
\text { Population }\end{array}$ & $\begin{array}{l}\text { Working } \\
\text { Age } \\
\text { Population }\end{array}$ & $\begin{array}{l}\text { Dependent } \\
\text { Population }\end{array}$ & $\begin{array}{l}\text { Working } \\
\text { Age } \\
\text { Population }\end{array}$ \\
\hline 1 & Nigeria & $2.60 \%$ & $2.70 \%$ & $0.70 \%$ & $2.00 \%$ \\
\hline 2 & Indonesia & $0.90 \%$ & $2.30 \%$ & $0.80 \%$ & $0.40 \%$ \\
\hline 3 & Pakistan & $2.50 \%$ & $3.00 \%$ & $1.00 \%$ & $1.80 \%$ \\
\hline 4 & East Asia & $0.50 \%$ & $1.90 \%$ & $0.90 \%$ & $-0.10 \%$ \\
\hline 5 & $\begin{array}{l}\text { Sub- } \\
\text { Sahara } \\
\text { Africa }\end{array}$ & $2.60 \%$ & $2.80 \%$ & $1.10 \%$ & $2.30 \%$ \\
\hline 6 & World & $1.10 \%$ & $1.90 \%$ & $0.80 \%$ & $0.70 \%$ \\
\hline
\end{tabular}

Table 1: Comparing the growth rates of the working-age and nonworking-age population Annual Average Growth Source: David Bloom et al. [4].

\begin{tabular}{|l|l|l|l|l|}
\hline S/N & $\begin{array}{l}\text { City (City with } \\
\text { 10 Million or } \\
\text { more) }\end{array}$ & $\begin{array}{l}\text { 2009 (Population } \\
\text { in Millions) }\end{array}$ & $\begin{array}{l}\text { 2025 (Projected } \\
\text { population in } \\
\text { millions) }\end{array}$ & $\begin{array}{l}\text { Overall } \\
\text { growth rate } \\
\text { (\%) }\end{array}$ \\
\hline 1 & Lagos, Nigeria & 10.2 & 15.8 & 54.9 \\
\hline 2 & $\begin{array}{l}\text { Bogota, } \\
\text { Columbia }\end{array}$ & 6.4 & 10.5 & 64.1 \\
\hline 3 & Mumbai, India & 19.7 & 25.8 & 31 \\
\hline 4 & $\begin{array}{l}\text { Manila, } \\
\text { Philippines }\end{array}$ & 11.4 & 14.9 & 30.7 \\
\hline 5 & $\begin{array}{l}\text { Karachi, } \\
\text { Pakistan }\end{array}$ & 12.8 & 18.7 & 46.1 \\
\hline 6 & Cairo, Egypt & 10.9 & 13.5 & 23.9 \\
\hline
\end{tabular}

Table 2: the World's Fastest Growing Cities .Source: Todaro/Smith [5]. Growth rate calculated by the researchers.

Another thing that has been observed about urban unemployment in LDCs is that it is most serious for people between the ages of 15 and 24 - often these are people who have had some level of schooling. The LDCs Report of 2011 examined the urban population and labour participation rate in 2009 . It was surprising to see that $87.7 \%$ of the population in Djibouti lives in the urban. Others included Angola (57.6\%), Gambia (57.4\%), Liberia (60.8\%), Sao Tome and Principe (61.3\%), Haiti (48.3\%), and Yemen (31.2\%) etc. The labour participation rates have not been encouraging as the large numbers going to the urban centers are not absorbed fully in productivity.

The fast rate of urban population in LDCs seems to be due to massive rural-urban migration, and high birth rate; but particularly the first factor. Most of the LDCs contribute to these problems by formulating policies - socio-economic policies that are urban biased policy of building the urban centers as growth poles for the rest of the 
economy. Programmes designed to achieve these policies have resulted in substantial imbalance between the urban centers and the rural areas in terms of incomes, income-earning opportunities, modern jobs, and social amenities such as pipe borne water, electricity, health facilities and educational infrastructures.

\begin{tabular}{|l|l|l|l|l|l|}
\hline S/n & Country & $\begin{array}{l}\text { Urban } \\
\text { Population } \\
(\%)\end{array}$ & \multicolumn{3}{|l|}{ Labour participation rates } \\
\hline & & & Male & Female & Total \\
\hline 1 & Angola & 57.6 & 88.4 & 74.5 & 81.3 \\
\hline 2 & Benin & 41.6 & 77.9 & 67.4 & 72.7 \\
\hline 3 & Djibouti & 87.7 & 78.7 & 61.5 & 70.1 \\
\hline 4 & Gambia & 57.4 & 85.2 & 70.6 & 77.8 \\
\hline 5 & Haiti & 48.3 & 82.9 & 57.5 & 69.9 \\
\hline 6 & Liberia & 60.8 & 75.8 & 66.6 & 71.1 \\
\hline 7 & $\begin{array}{l}\text { Sao tome } \\
\text { and } \\
\text { Principe }\end{array}$ & 61.3 & 76 & 44.5 & 59.8 \\
\hline 8 & Yemen & 31.2 & 73.5 & 19.9 & 46.8 \\
\hline 9 & $\begin{array}{l}\text { African } \\
\text { LDCs, and } \\
\text { Haiti }\end{array}$ & 30 & 85.1 & 68 & 76.4 \\
\hline 10 & Asian LDCs & 27.4 & 82.4 & 56.7 & 69.5 \\
\hline 11 & Island LDCs & 29 & 76.8 & 55.9 & 66.5 \\
\hline
\end{tabular}

Table 3: Urban Population and Labour Participation Rate 2009. Source: UNCTAD/LDC/2011.

A paper presented by Lucy Chang et al., written by A. G. Blomqvist, on "urban job creation and unemployment in LDCs: Todaro vs. Harris and Todaro", stated thus: "Many urban centers in developing countries are plagued by high rates of unemployment as shown in the Table 3. Yet, despite the fact that large numbers of urban workers are unemployed, urban centers still experience high rates of rural-tourban migration. A natural policy response has been to focus on job creation in urban sector, which in some cases has actually led to an increase in unemployment". Hence it can be deduced that the urban centers of the LDCs have been growing without creating jobs. This problem is still compounded, causing a menace due to "expectation mechanism" - a situation where people continue to migrate to the urban centers in search of jobs, even if such opportunities are not available.

A large and growing share of young people can support the economic and social development of countries, but can also pose considerable challenges, where countries do not have the capacity to ensure adequate investment, especially in their health and education, and where economies do not generate sufficient productive and remunerative employment for young people.

In contrast to many advanced countries, rapid urban growth and rural-urban migration in the least developed countries is often associated with negative economic and social developments. Many of these countries have a weak agricultural sector - characterized by low and often falling agricultural labour productivity and yields - and have at the same time a weak non-agricultural sector [1]. Since the limited employment options in agriculture and the lower potential wages associated with these activities, people living in rural areas move to urban centers. But because of the weak expansion of non-agricultural sectors - both industry and services - many cannot find formal employment in these sectors. They are more likely to be working in the informal sector than in the formal sector [1].

This is evident in most LDCs as majority of youths-graduates from tertiary institutions-end up working in the informal sector of the economy, mostly services - barbing salon, clerks etc - jobs meant for primary and secondary school leavers. Table 4 below depicts the geographic distribution of population and labour force (the economically active population) in LDCs.

\begin{tabular}{|c|c|c|c|c|c|c|}
\hline \multirow[b]{2}{*}{ LDCs } & & \multicolumn{2}{|c|}{$\begin{array}{l}\text { Distribution of } \\
\text { population (\%) }\end{array}$} & \multicolumn{2}{|c|}{$\begin{array}{l}\text { Absolute } \\
\text { numbers } \\
\text { (millions) }\end{array}$} & \multirow{2}{*}{$\begin{array}{l}\begin{array}{l}\text { Average } \\
\text { annual } \\
\text { change } \\
\text { (\%) }\end{array} \\
2000-201 \\
0\end{array}$} \\
\hline & & 2000 & 2010 & 2000 & 2010 & \\
\hline \multirow{2}{*}{$\begin{array}{r}\text { Total } \\
\text { population }\end{array}$} & Urban & 25 & 30 & 168.4 & 252.4 & 4 \\
\hline & Rural & 75 & 70 & 508.7 & 602.4 & 1.7 \\
\hline \multirow{2}{*}{$\begin{array}{l}\text { Labour } \\
\text { Force }\end{array}$} & Agricultural & 70 & 65 & 199.6 & 244.8 & 2 \\
\hline & $\begin{array}{l}\text { non- } \\
\text { agricultural }\end{array}$ & 30 & 35 & 84.2 & 130.5 & 4.4 \\
\hline \multicolumn{7}{|l|}{$\begin{array}{l}\text { African } \\
\text { LDCs }\end{array}$} \\
\hline \multirow{2}{*}{$\begin{array}{l}\text { Total } \\
\text { population }\end{array}$} & Urban & 26 & 31 & 105.8 & 162.3 & 4.3 \\
\hline & Rural & 74 & 69 & 300.1 & 369.7 & 2.1 \\
\hline \multirow{2}{*}{$\begin{array}{l}\text { Labour } \\
\text { Force }\end{array}$} & Agricultural & 76 & 71 & 126.1 & 160.9 & 2.4 \\
\hline & $\begin{array}{l}\text { non- } \\
\text { agricultural }\end{array}$ & 24 & 29 & 40.7 & 65.7 & 4.8 \\
\hline \multicolumn{7}{|l|}{ Asian LDCs } \\
\hline \multirow{2}{*}{$\begin{array}{r}\text { Total } \\
\text { population }\end{array}$} & Urban & 23 & 28 & 62.6 & 90.2 & 3.6 \\
\hline & Rural & 77 & 72 & 208.6 & 232.7 & 1.1 \\
\hline \multirow{2}{*}{$\begin{array}{l}\text { Labour } \\
\text { Force }\end{array}$} & Agricultural & 63 & 56 & 73.5 & 83.9 & 1.3 \\
\hline & $\begin{array}{l}\text { non- } \\
\text { agricultural }\end{array}$ & 37 & 44 & 43.5 & 64.9 & 4 \\
\hline
\end{tabular}

Table 4: Geographic Distribution of population and labour force in LDCs, 2000-2010 [3].

Out of the population of the LDCs, 70\% accounting for 199.6 million people are engaged in agriculture while 84.2 million (30\%) are absorbed in non-agricultural activities. $25 \%$ dwells in the urban centers while $75 \%$ reside in rural areas. The African LDCs comprise of $26 \%$ urban and $74 \%$ rural dwellers while the Asian LDCs is characterized by 62.6 million people in 2000 and 90.2 million people in urban centers (23\%). The labour force participation in the agricultural sector of African LDCs surpasses that of Asian LDCs', while Asian LDCs' population engaged in non-agricultural activities surpasses that of African LDCs'. 
Observing the trend, rural-urban migration tendency is possible as the number engaged in agricultural activities in both LDCs reduces in 2010. The non-agricultural activities, mainly in the urban centers, are occupied indicated by increases in 2010. This is evident in the average annual change of $4.0 \%$ urban dwellers and $4.4 \%$ non-agricultural activities during the span of 10 years (2000-2010).

Many LDCs not only confront the challenge of creating more jobs as highlighted by pervasive unemployment, underemployment and vulnerable employment - the LDCs simultaneously confront the challenge of creating more productive, remunerative and decent work - as highlighted by widespread working poverty.

\begin{tabular}{|l|l|l|l|}
\hline $\mathbf{S} / \mathbf{N}$ & Country & $\mathbf{1 9 9 5 ( \% )}$ & $\mathbf{2 0 0 5 ( \% )}$ \\
\hline 1 & Northern Africa & 33.9 & 34.5 \\
\hline 2 & Western Asia & 20.8 & 23.6 \\
\hline 3 & Sub-Sahara Africa & 18 & 18.3 \\
\hline 4 & Eastern Asia & 7.8 & 7.8 \\
\hline 5 & $\begin{array}{l}\text { Latin America and } \\
\text { Caribbean }\end{array}$ & 14.2 & 15.2 \\
\hline 6 & Oceania & 7.9 & 6.6 \\
\hline
\end{tabular}

Table 5: Youth unemployment rate 1995-2005 [5].

Table 5 depicts the rate of unemployment among youth in various regions. The worst hit is northern Africa with $33.9 \%$ in 1995 and $34.5 \%$ in 2005. Sub-Sahara Africa is $18 \%$ in 1995 and $18.3 \%$ by 2005 . Eastern Asia recorded as low as 7.8\% in 1995 and 7.8\% in 2005.

Predictably, between now and 2050, the working-age population of the LDCs will increase by an annual average of about 15 million, and the labour force of the LDCs will increase by about thousand per day over the next forty years, on average [1].

Most of the youth are absorbed in the already occupied informal sectors waiting to get an opportunity in the formal sector, notwithstanding the gender dimension inherent in these countries with unemployment, underemployment and vulnerable employment. This is especially pervasive amongst younger entrants in the labour market and amongst those with lower educational attainment.

\section{The Nigerian Scenario}

Nigeria has the largest population in Africa and among the black race of the world. Nigeria is firmly within the category of a very youthful age structure, with nearly three-quarters of its population under the age of 30 . Nigeria's population has actually grown more unbalanced in recent decades. Between 2006 and 2011 the share of young people in the country's population increased while the share of older adults slightly decreased, and thus Nigeria has reversed course along the path of the demographic transition - an anomaly in the process of most countries' development.

According to THE NEXT GENERATION PROJECT 20115, "Nigeria is currently poorly positioned to maximize the economic opportunities created by its demographics, despite marked improvements in the policy environment and past decades".

From the 2011 population pyramid by the National Population Commission and World Bank Growth, young Nigerians between age
20 to 40 make up $47 \%$ of the nation's population, which provides a window of opportunity for high growth, economic opportunities and poverty reduction - the demographic dividend - representing a huge potential resource to Nigeria given the critical role of the youths in strengthening the nation's economy (Figure 1).

Nigeria, have the opportunity to turn the youth bulge into a "demographic dividend" or active and productively engaged youthful population, that can power economic growth and development otherwise, this bulge is a ticking time bomb waiting to explode into a youth "disaster" which in the face of scarce economic opportunities become disillusioned and frustrated, imperiling an already fragile socio-political stability.

One of the key findings of the report states: "Nigeria stands on the threshold of what could be the greatest transformation in its history. By 2030, it will be one of the few countries in the world that has young workers in plentiful supply. Youth, not oil, will be the country's most valuable resource in the 21 st century". This sounds interesting. But the question is "how would this happen given the deplorable state of our human capital.' Realistically, most youth lack mental skill and practicability.

According to a 2006 IMF report, "the skills of the labor force, built largely during childhood and youth, are an important determinant of a country's overall investment climate". These skills are built when primary, secondary and tertiary education opportunities are provided to young people. Nigeria's challenges in providing education are well documented, with literacy rates of the $15-24$ age range at $65 \%-75 \%$ for females and males with stark regional variations between the Northern and Southern parts of the country. While enrolment and completion rates have increased for primary education, the enrolment rate remains low for secondary education, at $25.8 \%$ according to World Bank 2010 figures.

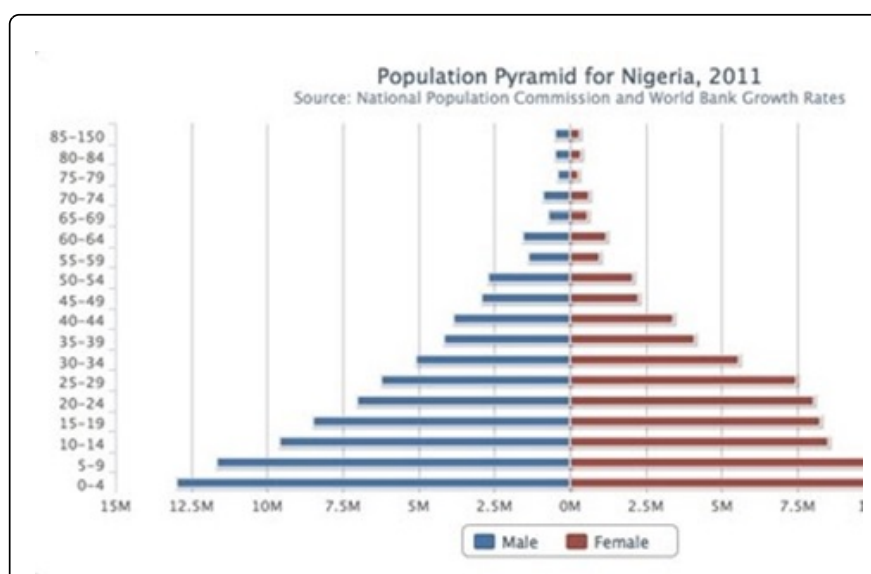

Figure 1: Population Pyramid for Nigeria, 2011. Source: National Population Commission.

Importantly, very few of these have access to quality education across all three levels. Decaying equipment and facilities, poorly qualified teachers sometimes barely able to speak English, poorly equipped universities and tertiary institutions have all resulted in consecutive mass national failure in secondary school leaving certificate exams - up to $98 \%$ in the 2009 NECO exams - and halfbaked graduates from tertiary institutions, at best unable to write formal application letters and at worst lacking transferable skills, for a 
career path they are already uncertain of. Poor funding, corruption and persistent systemic decay of the education sector are all key factors resulting in a poorly educated and largely unskilled youth demographic.

\section{Nigeria's Unemployment Rate}

Unemployment is a major concern to every well-meaning Nigerian. Nigeria's growing unemployment is one of a major concern to many analysts and economists as the Figure 2 increasingly suggest dwindling potentials. "Official figures from the Bureau of Statistics puts this figure at about $20 \%$ (about 30 million), but this figure still did not include about 40million other Nigerian youths captured in World Bank statistics in 2009. By implication, it means that if Nigeria's population is 160 million, then $50 \%$ of Nigerians are unemployed, or worse still, at least $71 \%$ of Nigerian youths are unemployed. This is particularly disturbing and counterproductive because at least $70 \%$ of the populations of this country are youths." (See article www.saharareporters.com).

Unemployment and underemployment is seriously confronting the Nigerian youth in all ramifications. The increase in population of Nigerians is one of the challenges facing the labour market which the government on its part failed to provide full employment to its citizenry. Many Nigerians today are underemployed despite their intimidating credentials being possessed in high flying institutions in the world together with economic recession and inconsistent policies in the country.

It is unfortunate that Nigeria has been unable to resolve the employment debacle that has been undermining the well-being of many Nigerians for a number of years now. More depressing, still, is the fact that many youths have remained stranded outside the vortex of the nation's economy. This situation portends disaster for any nation. No country can expect peace and progress when its youths are kept idle, angry and unfulfilled. It is a recipe for social unrest and disaster. The percentage of unemployed Nigerians is likely much higher than we have been told, and the number of youths that are unable to find jobs has already reached dangerous heights. Apart from the unemployed, Nigeria also has a high percentage of the underemployed - that is, those whose income, are so low that they cannot afford the basic necessities of life such as food, clothing and shelter.

Unemployment Rate in Nigeria increased to $23.90 \%$ in 2011 from $21.10 \%$ in 2010. Historically, from 2006 until 2011, Nigeria Unemployment Rate averaged $14.6 \%$ reaching an all-time high of 23.9\% in December of 2011 and a record low of 5.3\% in December of 2006. In Nigeria, the unemployment rate measures the number of people actively looking for a job as a percentage of the labor force. This chart shows the historical data for Nigeria Unemployment Rate.

Of course youth unemployment is a not a phenomenon exclusive to Nigeria or Sub-Saharan Africa as many developed countries, are plagued by high youth unemployment rates with the recent global economic downturn. However, if countries like Nigeria are to avert a demographic disaster already incubating a lost generation vulnerable to drug addiction, militancy, insurgency and general disillusionment, then it is imperative that this youthful population is productively engaged. There are indeed factors responsible for this cankerworm in the system - the employment problem [6].

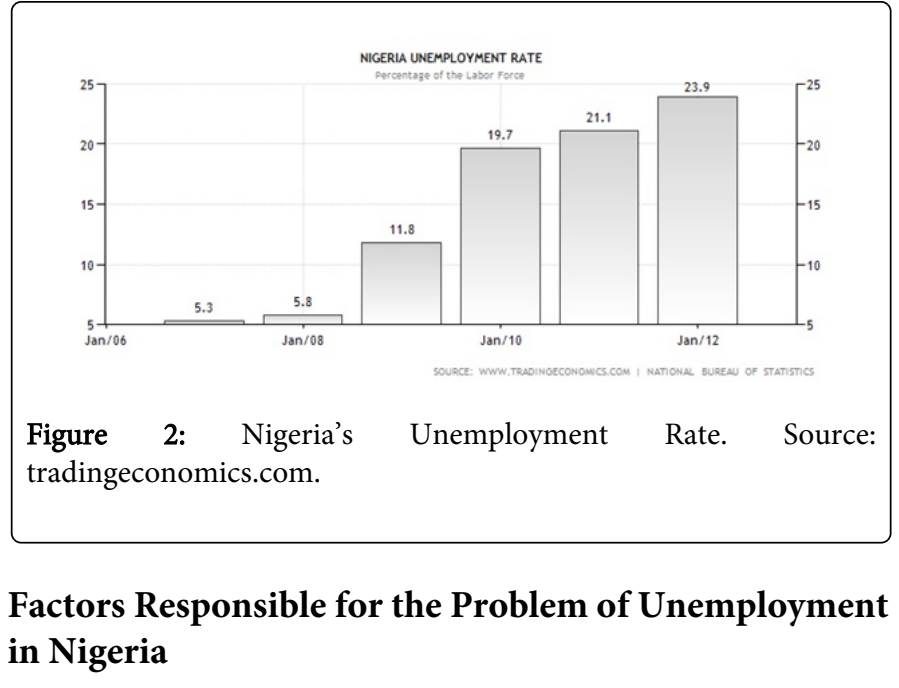

\section{Rural-urban migration}

One of the factors causing employment problems is rural urban migration. People want to earn a good level of income, good health system etc. This is evident in the large urban population of most Nigeria's cities (Lagos, Abuja, Port Harcourt and Kano). This creates large numbers of urban population and slum population as a result of the 'expectation mechanism'. Observing the trend, unemployment is moving along the educational ladder. Jobs meant for the first school leaving certificate holders are competitively occupied by university and polytechnic graduates. The competition to get a very good job is high.

\section{Government policies}

Government policies are mostly focused on the urban sectors. As noted earlier, the inability of the government to initiate adequate capital projects in rural areas has caused increased rural-urban migration leading to congestion. Apart from that, the high incidence of corruption in public service makes implementation of most government polices impossible. According to Godday Odidi, "Youth unemployment should be blamed on both the private and public sectors of the country. The government has abysmally failed to provide for unskilled, semi- skilled and skilled people at all levels".

\section{Urban bias}

Most of the fiscal expenditures of the government are focused on the urban centers. Hence the programmes of the federal government are urban biased. It has always been the case starting from the National Development Plans. One such study, undertaken as far back as 1991 produced the following findings. Table 6 illustrates the level of urban biasness when it comes to executing government projects.

\begin{tabular}{|l|l|l|l|l|l|l|}
\hline Sector & $\begin{array}{l}\text { Rural } \\
\text { planned }\end{array}$ & Actual & $\begin{array}{l}\text { Urban } \\
\text { planned }\end{array}$ & Actual & $\begin{array}{l}\text { Rural } \\
\text { urban } \\
\text { planned }\end{array}$ & Actual \\
\hline Industry & 3.4 & 8.9 & 96.7 & 91.1 & 0 & 0 \\
\hline $\begin{array}{l}\text { Commerce \& } \\
\text { finance }\end{array}$ & 4.9 & 2.2 & 86.7 & 96.8 & 8.4 & 1 \\
\hline Electricity & 21.9 & 23.9 & 78.1 & 76.1 & 0 & 0 \\
\hline
\end{tabular}


Page 6 of 7

\begin{tabular}{|l|l|l|l|l|l|l|}
\hline Communication & 0.1 & 0.1 & 97.5 & 98.4 & 2.3 & 1.5 \\
\hline Health & 13.3 & 7.2 & 50 & 75.7 & 36.6 & 17.1 \\
\hline Information & 0 & 0 & 67.4 & 53.2 & 32.6 & 46.8 \\
\hline Social welfare & 0.4 & 0.5 & 68.3 & 84.8 & 31.3 & 14.7 \\
\hline $\begin{array}{l}\text { Water supply \& } \\
\text { sewerage }\end{array}$ & 23.6 & 20 & 68.2 & 70.6 & 8.2 & 9.4 \\
\hline Drainage & 0 & 0 & 100 & 100 & 0 & 0 \\
\hline $\begin{array}{l}\text { Town and } \\
\text { country planning }\end{array}$ & 2.5 & 1.3 & 88.7 & 89.3 & 8.8 & 9.4 \\
\hline $\begin{array}{l}\text { Cooperatives } \\
\text { and supply }\end{array}$ & 9.9 & 16.4 & 16.5 & 9 & 73.6 & 74.5 \\
\hline $\begin{array}{l}\text { Community } \\
\text { development }\end{array}$ & 74.2 & 84.3 & 7 & 15.7 & 18.7 & 0 \\
\hline Labour & 0 & 0 & 100 & 100 & 0 & 0 \\
\hline Housing & 0 & 0 & 100 & 100 & 0 & 0 \\
\hline $\begin{array}{l}\text { General } \\
\text { administration }\end{array}$ & 0.7 & 0 & 34.5 & 41.8 & 14.8 & 58.2 \\
\hline $\begin{array}{l}\text { Defence } \\
\text { security }\end{array}$ & 0 & 0 & 39 & 9.2 & 61 & 90.8 \\
\hline
\end{tabular}

but certificate thereby missing the essential ingredients for human capital development.

\section{Corruption}

Corruption is a cankerworm that has eaten deeply into the Nigerian economy. This also has exacerbated the problem of employment in Nigeria, a country with abundant resources. As Good Wilson puts it, "In the case of Nigeria, the problem however, is not due to lack of land, water, labour etc. as they are all available in abundance, but that of inability to mobilize the abundant resources occasioned by corruption and mismanagement to provide adequate opportunities for the country's seemingly teeming population".

\section{Inspirited Entrepreneurship Drive}

It is important to note that entrepreneurship drive in Nigeria is diluted with ineptitude among youths. The environment is hostile and unpleasant for entrepreneurship to strive. According to Adawo et al. [9-13], "The Nigerian infrastructural system limits entrepreneurial effectiveness and is a barrier to success. Lack of electricity, poor communication system, insecurity and corruption are all inimical to entrepreneurship, the spirit of entrepreneurship does not sit high in people's economic consciousness". Truly, the hostile environment blurs the wonderful prospect of a large number of youth to develop a well-spirited drive for entrepreneurial success.

Table 6: Rural-Urban Distribution of Government Investment Spending in The Third National Development Plan 1975-1980 [7].

The investment spending by the government would definitely have an impact on the urban centers at the expense of rural areas. Looking intently at the data, the percentage of government planned activities in rural areas is low and the actual execution is very discouraging.

On the other hand, the urban centers get the greatest share of the plans and the execution rate for most of the sectors is greater than the planned. This shows the level of urbanization and its biasness when it comes to addressing the problems of unemployment. The rural urban planned policies are also below expectation given the urban bias syndrome. The actual execution rate, with exception of defense, is "nothing to write home about".

\section{Lack of Population Control}

Lack of population is also a factor that causes employment problems. The number of jobs available will determine the number of youths to be employed in any country. The Nigerian government was able to provide jobs for its youths in the past because the population of the country then was not as much as it is now. The rate at which Nigerians give birth should be limited as uncontrolled procreation contributes more to the challenges facing the country.

\section{Lack of Mental Skill and Practicability}

This has been analyzed previously. There is always the saying that 'Nigerian graduates are unemployable'. This is possible as the education system is degraded when it come to preparing potential graduates for the labour market. As described by Akpakpan [8] "Education has not produced effects that were expected in Nigeria: the knowledge, skills and attitudes by which economies and societies are transformed". This is evident as graduate no longer care for knowledge

\section{Conclusion and Recommendations}

Clearly, employment problems can be created only if the government does not set up adequate measures to control population and to distribute resources equitably giving a sense of belonging to all citizens. Therefore, to provide the teeming controlled population the needed employment opportunities, there is need to efficiently allocate resources and initiate projects towards employment generation. This is needed to avoid a "worst case scenario" as postulated by THE NEXT GENERATION TEAM, "In worst case, Nigeria will see growing numbers of restless young people frustrated by lack of opportunity; increased competition for jobs, land, natural resources, and political patronage; cities that are increasingly unable to cope with the pressures placed on them; ethnic and religious conflict and radicalization; and a political system discredited by its failure to improve lives". With full determination, the change we dearly crave for would be achieved. In order to achieve this, the following recommendations were made:

Review the socio-economic organization. Economic leadership is missing in the country. We must distinguish between economic leadership and political leadership. When we talk about economic leadership; there are over 160milion mouths to feed, clothe and provide their other basic needs, so there is huge demand; how do you fill this demand? The old model of governance must change. We need to think out of the box, old tradition must begin to fade away. We should look at the economy in clear terms of demand and supply. Let the demand be the 160million people and the supply, be all the possible jobs, companies, investments, which when well-articulated we would have a more robust economy that will address the unemployment problem.

Rural-urban migration should be reduced. People migrate to the urban centers to seek for opportunities based on their expectations. The jobs readily available are insufficient for the competitive large 
number of applicants. The government should set up policies in order to develop the rural areas for employment generation. This would offload the burden on the urban centers and at the same time, create jobs for the teeming working population.

Agriculture should be promoted. This requires designing and implementing policies that make the sector more attractive than it is today. These should include a better organization of the sector in terms of both production and marketing. Substantial government participation is necessary in view of inadequacy of private operators in Nigeria. This would also help in focusing on the rural areas thereby reducing the degree of dualism and urban bias.

Pursue a programme of selective industrialization, that is, select industries for promotion according to their potential impact on stimulation of demand for local materials and labour.

The ministry of labour should not limit its responsibilities to resolving problems with labour unions that were instigated by the government, in the first place. Instead, it should be in the forefront of the efforts to keep Nigerians productively engaged. In addition, all persons and institutions charged with implementation of employment and poverty reduction programmes should be properly monitored to ensure that they remain faithful to the stated objectives. In this 21 st century, certain key sectors have been noted to have capacity to absorb job seekers. These include agriculture, industry and technology, especially Information Communication Technology (ICT). Many of our youths who now employ ICT for criminal purposes can be reoriented towards employment or job creation in that sector. The Federal Government has proposed to create 320,000 jobs beginning from this year. Finance Minister, Dr. Ngozi Okonjo-Iweala, said the proposal has already been built into the 2013 Appropriation. Although this figure is a far cry from the one million jobs promised annually by the government earlier, we urge that everything necessary should be done to make the fresh promise a reality.

Employment generation is a function of adroit Sound Economic Policies, Government job creation schemes, existence of an enabling environment - infrastructure, law and order and an efficient regulatory system - and private sector initiatives, flourishing within this environment to create job opportunities.

Encourage entrepreneurship and fully incorporate the citizens in such programmes. A skilled populace, given the right incentives interacts favorably with this business-friendly environment to be productive citizens. However, Nigeria remains a country with immense untapped potential - vibrant population, large market - and an even greater potential of harnessing all these for economic prosperity, but for the most part, the full transition from "potential" to "actuality" is yet to takeoff. This difficult terrain not only stifles entrepreneurial innovation but has engendered a survival-of-themost-connected fierce competition for scarce and "lucrative" public sector jobs. Lofty poverty alleviation programs have characterized government employment generation initiatives through President Jonathan's You WIN (Youth Enterprise with Innovation), the Subsidy and Reinvestment and Empowerment Programme (SURE-P), and the CBN - Sponsored Entrepreneurial Development Centres7 in Nigeria.
These interventions of supporting aspiring entrepreneurial youth hold some hopeful prospects for employment generation.

Encourage Public-Private Partnership (PPP). There are specific junctures where non-government actors could stage interventions in complementing government efforts in providing adequate education, employment and economic opportunities, to turn this impending youth-bulge disaster into a dividend.

Enhance Family - Planning Problems. Family planning should be embraced. It is relevant given the fact that there are large numbers of potential parents. Manipulating economic incentives and disincentives for having children would prove effective.

Investment in human capital must be substantially boosted. The government should set target for increasing expenditure on education and health, using oil revenue to fund both infrastructure and recurrent spending, while ensuring that existing funds are spent more efficiently.

\section{References}

1. United Nations Conference on Trade and Development (UNCTAD) "The Least Developed Countries Report 2011".

2. Curtain R (2004) Paper for expert group meeting on "Strategies for creating urban youth employment: solutions for urban youth in Africa". Department of Economic and Social Affairs, United Nation, Nairobi, Kenya.

3. United Nations Population Fund (UNFPA) "Population Dynamics in the LDCs: Challenges and Opportunities for Development and Poverty Reduction".

4. Bloom DE, Humair S (2010) "Economic Development in Nigeria: A Demographic Perspective Committee on African Seminar".

5. Todaro MP, Smith SC (2011) "Economic Development", Eleventh Edition. Pearson Education Limited, Edinburgh Gate, Harlow, England.

6. Trading Economics. Com (website) Diagram on Nigeria's Unemployment Rate.

7. Okowa WJ (1991) "Political Economy of Development Planning in Nigeria", Paragraphics Publishers, Port Harcourt, Nigeria.

8. Akpakpan EB (2011) "Education for National Development. How well has Nigeria done?" Journal of National Association of Female Teachers (JONAFET) 3: 5-15.

9. Adawo MA, Atan JA (2013) "Graduate unemployment in Nigeria: Entrepreneurship and Venture Capital Nexus". J of Econ and Sustainable Development 4: 43-56.

10. Blomqvist AG (1992) "Urban Job Creation and Unemployment in LDCs: Todaro vs Haris and Todaro" Presented by Lucy Chang.

11. Bloom DE, Freeman RB (1986) "Population Growth Labour Supply and Employment in Developing Countries". UBER Working Paper No. 141837.

12. Wilson G (2002) "Development Economics - A concise text". Pearl Publishers. Port Harcourt, Nigeria.

13. Nigeria, the Next Generation Report (2011) Chaired by Ngozi OkonjoIweala (Managing Director of the World Bank) and David Bloom (Clarence James Gamble Professor of Economics and Demography at the Harvard School of Public Health). Task Force members (Alhaji Lamido Ado Bayero, Donald Duke, Frank Nweke, Lord Triesman, Pat Utomi and Maryam Uwais). 